\title{
ULTRASTRUCTURAL ALTERATIONS OF INTRACELLULAR STAGES AND EFFECTS ON BLOOD FORMS OF TRYPANOSOMA CRUZI INDUCED IN VIVO BY 2-AMINO-5-(1-METHYL-5-NITRO-2-IMIDAZOLYL)-1,3,4- THIADIAZOLE 1
}

\author{
Thaisa de Almeida Maria2, Leny de Sousa Filardi3 and Zigman Brener4
}

\begin{abstract}
An electron microscopy study shows that the administration of a single dose (500 mg/kg, p.o.) of 2-amino-5-(1-methyl-5-nitro-2-imidazolyl)-1, 3, 4-thiadiazole induces in mice infected with Trypanosoma cruzi results in degenerative lesions of the intracellular stages. Ultrastructural alterations are detected as early as 6 hours after the drug administration and destruction of the parasites occurs within 18 - 36 hours. Trypomastigotes are cleared from the bloodstream 4 to 6 hours after treatment. The combined effect on both developmental stages is apparently responsible for the in vivo effects of this drug which is the most active drug ever tested in our laboratory in experimental Chagas' disease.
\end{abstract}

Key words: Trypanosoma cruzi. Nitroimidazo-thiadiazole. Electron microscopy.

Recent investigation has demonstrated a remarkable curative effect of 2-amino-5-1 (1-methyl-5nitro-2-imidazolyl)-1, 3, 4-thiadiazole in mice experimentally inoculated with Trypanosoma cruzi ${ }^{6}$. The drug has been further investigated in vivo and we now report the fine structure alterations of $T$. cruzi intracellular stages in treated animals as well as an intense suppressive action on circulating blood forms induced by the compound. The early and intense activity of this drug on both parasite stages explains its unusual high curative effect in experimental Chagas' disease.

\section{MATERIALS AND METHODS}

Ultrastructural studies. Male albino mice weighing $18-20 \mathrm{~g}$ were intraperitoneally inoculated with $5 \times 10^{4}$ blood trypomastigotes of the Colombiana strain1. 2-amino-5-(1-methyl-5-nitro-2-imidazolyl)1, 3, 4-thiadiazole (CL 64'855, "Megazol") was given by oral route in a single dose of $500 \mathrm{mg} / \mathrm{kg}, 12$ days after inoculation. Untreated mice inoculated with the same inoculum were used as controls. Both treated and control animals were sacrificed $6,12,18,24$ and 36 hours

1. Supported by CNPq-FINEP.

2. Departamento de Morfologia, ICB/UFMG.

3. Departamento de Zoologia, ICB/UFMG.

4. Centro de Pesquisas René Rachou, FIOCRUZ, Av. Augusto de Lima, 1715 - C.P. 1743, 30.000 - Belo Horizonte, Brasil (Address for Correspondence).

Recebido para publicação em 15/12/83. after treatment. The heart was removed and fixed in $2.5 \%$ glutaraldehyde in $0.1 \mathrm{M}$ phosphate buffer. The organ was sectioned at the level of the atrio-ventricular septum; the atria were then kept for 12 hours at $4{ }^{\circ} \mathrm{C}$ in the glutaraldehyde solution, post-fixed with $1 \%$ osmiun tetroxide in $0.1 \mathrm{M}$ phosphate buffer for 3 hours, dehydrated in alcohol series and, finally, embedded in Epon. Ultrathin sections were obtained in a $\mathbf{M T}_{2}$ Porter Blum ultra-microtome, stained in uranil acetate and Reynold's stain, and examined in a Zeiss EM-10 electron microscope.

Effect on bloodstream forms. The technique described by Filardi \& Brener 7 was used, as follows: male albino, weighing $18-20 \mathrm{~g}$, were inoculated with $1 \times 10^{5}$ bloodstream forms of strains Colombiana 1 , VL-1011 and $C L^{3}$. At the peak of parasitemia (which was at days $9-11$ with $C L$ strain and $15-20$ with Colombiana and $V L-10$ strains) the animals received a single dose of $500 \mathrm{mg} / \mathrm{kg}$ of the drug by oral route. A group of inoculated but untreated animals was used as control. The parasitemia was determined according to Brener ${ }^{2}$ before and 6 hours after drug administration. The reduction in the number of parasites was estimated by comparing the number of parasites after treatment with that detected before drug administration.

\section{RESULTS}

A remarkable finding of the ultrastructural study was the occurrence of extremely early alterations of $T$. cruzi intracellular stages. Whereas in the controls the parasites displayed normal morphology 
Maria TA, Filardi LS, Brener Z. Ultrastructural alterations of intracellular stages and effects on blood forms of Trypanosoma cruzi induced in vivo by 2-amino-5-(1-methyl-5-nitro-2-imidazolyl)-1, 3, 4-thiadiazole. Revista da Sociedade Brasileira de Medicina Tropical 17: 89-93, Abr-Jun, 1984

(Fig. 1) a number of ultrastructural alterations were observed as soon as 6 hours after drug administration in the treated animals. The initial lesions were vacuolization of the cytoplasm followed by swelling of the nuclear envelope, rough endoplasmic reticulum and Golgi cisterns (Fig. 2); a similar swelling was detected in the area around the fibrils network of the kinetoplast. These ultrastructural changes are progressively more severe in the animals sacrificed at the further periods of examination after treatment, showing a clear reduction of the number of ribosomes and other cytoplasmic components after 18 hours (Fig. 3). Even in those degenerated parasites some structures remain apparently intact such as the sub-pellicular microtubules, plasmatic membrane and the kinetoplast fibril network. At 36 hours degenerated forms displaying partial or total lysis are highly predominant (Fig. 4). In the untreated control group the great majority of the intracellular stages remained morphological normal.

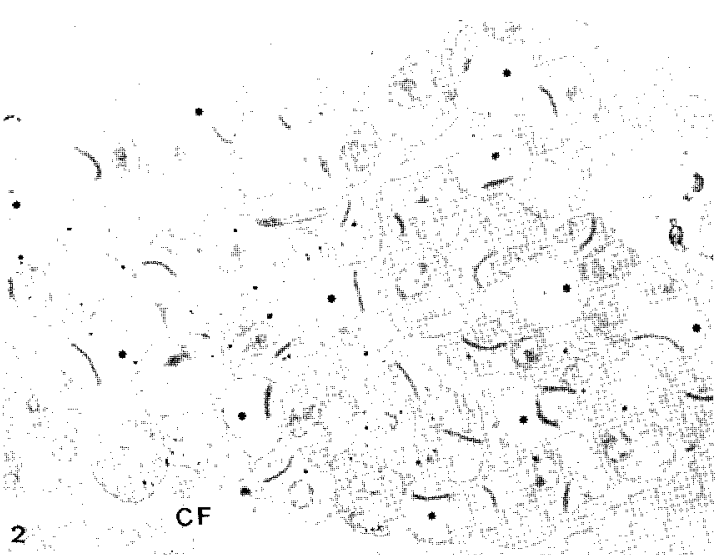

Fig. 2 - Treated, 6 hours. $T$. cruzi intracellular amastigotes showing early vacuolization of the cisterns of the endoplasmic reticulum, nuclear envelope and kinetoplast. $\mathrm{X} 5,700$.

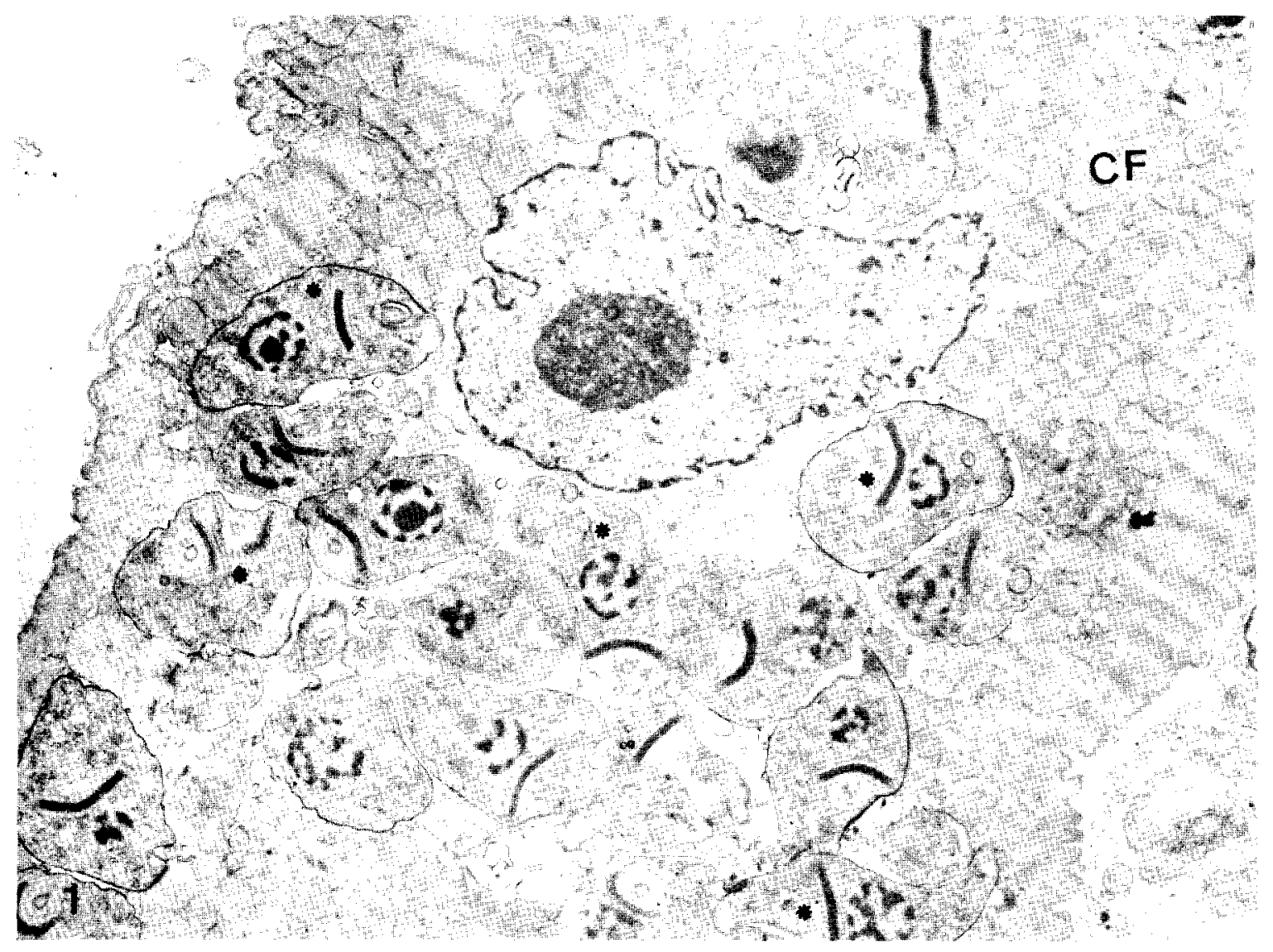

Fig. 1 - Control. T. cruzi intracellular amastigotes (asterisk) displaying normal morphology inside the cardiac fibre (CF). $\mathrm{X} 7,300$. 


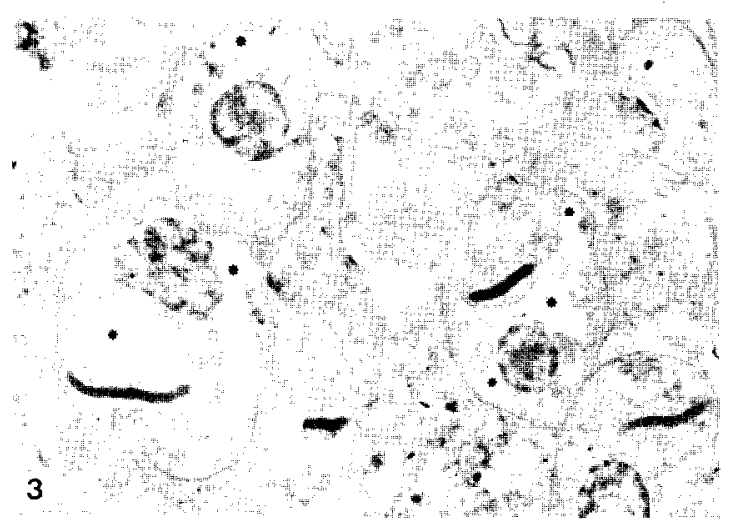

Fig 3 - Treated, 18 hours. T. cruzi intracellular amastigotes with progressive lesions of the membranous structures of the endoplasmic reticulum and nuclear envelope; and rarefaction of the cytoplasmic components. X 13,000.

Fig. 5 shows the effects of CL $64^{\prime} 855$ on the parasitemia in mice inoculated with $T$. cruzi strains $V L-10$, Colombiana and $C L$. A marked and rapid decline in the number of circulating trypomastigotes was observed as soon as 6 hours after drug administration, showing that the early effects on blood forms parallel that described for the intracellular stages.

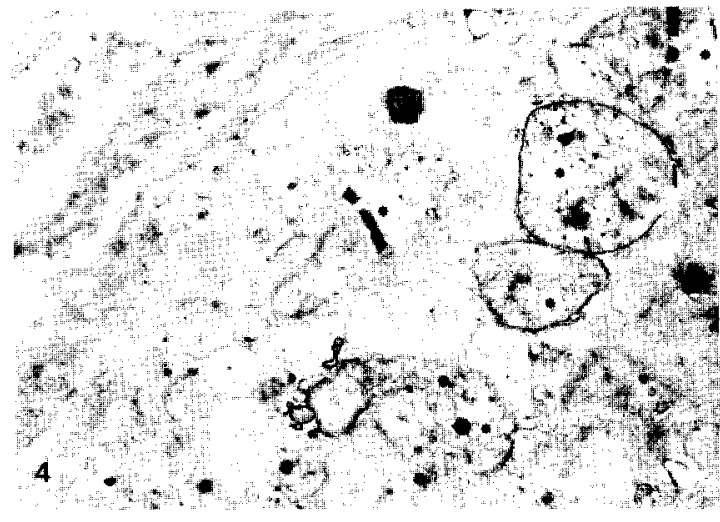

Fig 4 - Treated, 36 hours. $T$. cruzi degenerated amastigotes. Lysis of membranes and cytoplasmic components. X 10.700.

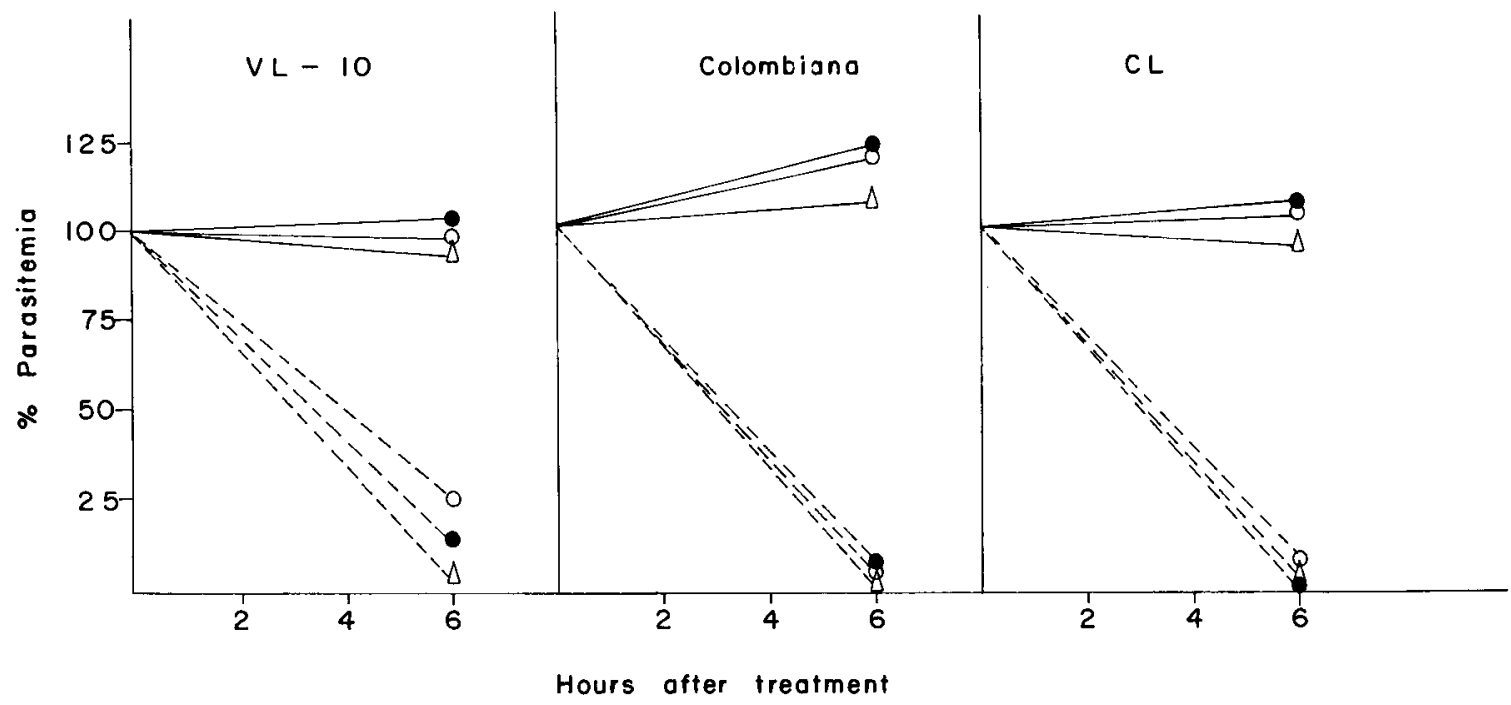

Fig. 5 - Reduction of parasitemia induced by a single dose $(500 \mathrm{mg} / \mathrm{kg}$, oral route) of CL 64'855 in mice inoculated with strains VL-10, Colombiana and CL of $T$. cruzi. Experiments performed with groups of three mice. Animal controls are represented by solid lines (-) and treated by dashed lines (-). 
Maria TA, Filardi LS, Brener Z. Ultrastructural alterations of intracellular stages and effects on blood forms of Trypanosoma cruzi induced in vivo by 2-amino-5-(1-methyl-5-nitro-2-imidazolyl)-1, 3, 4-thiadiazole. Revista da Sociedade Brasileira de Medicina Tropical 17: 89-93, Abr-Jun, 1984

\section{DISCUSSION}

The compound 2-amino-5-(1-methy1-5-nitro2-imidazolyl)-1, 3, 4-thiadiazole is apparently the most active drug so far tested against $T$. cruzi experimental infections 6 . According to our data it cures $85-100 \%$ of the inoculated animals treated for 20 days with doses of $50-100 \mathrm{mg} / \mathrm{kg}$; single doses of $500 \mathrm{mg} / \mathrm{kg}$ cure $88.8 \%$ of mice inoculated with the $T$. cruzi $Y$ strain. Moreover, it also cures $85-100 \%$ of the animals inoculated with strains Colombiana and VL-10 which are highly resistant to nitrofuran and 2-nitroimidazol derivatives 111 . In this paper we describe the effects of this drug on both intracellular and circulating $T$. cruzi stages. The early and marked effects of single doses apparently provide an explanation for high curative rates detected after single drug administration and strongly indicate an irreversible curative action of this compound.

The pattern of the intracellular parasite destruction with compound CL 64'855 seems "to be similar to that found in animals or in tissue culture treated with nitrofurazone ${ }^{4}$ and nifurtimox ${ }^{12}$. Basically, they consist of an increase in the number of cytoplasmic vacuoles, reduction of the ribosomes and swelling of the organelles. The process ends in the lysis of the parasites with persistence of the plasma membrane and the kinetoplast. The molecular mechanism of the lesions induced by CL $64^{\prime} 855$ is not yet known. Docampo et al ${ }^{5}$ demonstrated that incubation of $T$. cruzi homogenates with a nitrofuran derivative ("nifurtimox") favors the appearance of a nitroaromatic anion radical which reacts with oxygen and induces an increased rate production of superoxide anion and hydrogen peroxide, which are involved in the trypanocidal effect. Benznidazole (a nitroimidazole derivative), however, is not reduced to the nitro anion radical and does not induce generation of superoxide and hydrogen peroxide. This suggests a different (but not yet defined) mechanism of toxicity for nitroimidazole derivatives ${ }^{10}$. Since CL $64^{\prime} 855$ is a nitroimidazole with a thiadiazole component, the mechanism of this novel compound should be specifically investigated in comparison with the nitrofuran and nitroimidazole active compounds.

The effect of drugs on blood forms has been less investigated. Haberkorn \& Gönnert ${ }^{8}$ using a special reflex microscope observed in living blood trypomastigotes from mice treated with nifurtimox lesions such as cytoplasm vacuolization and membrane splitting. In our experiments the decline in the number of circulating trypomastigotes occurs very soon after drug administration and parallels the early action against intracellular stages. Data from our laboratory show that macrophages play an important role in the clearance of blood parasites by removing the circulating trypomastigotes in a process which begins very soon after the drug administration ${ }^{9}$. The effect on both intracellular and circulating stages is responsible for the rapid and extremely intense activity of this compound.

\section{RESUMO}

Um estudo com microscopia eletrônica mostrou que a administraf̧ão de dose única $(500 \mathrm{mg} / \mathrm{kg}$. p.o.) do composto 2-amino-5-(1-metil-5-nitro-2-imidazolil)-1, 3, 4-tiadiazole induz, em camundongos inoculados com $\mathrm{T}$. cruzi, lesões degenerativas das formas intracelulares do parasita. Alterações ultra estruturais são observadas 6 horas após a administração da droga e destruição ocorre em 18 - 36 horas. Tripomastigotas também desaparecem do sangue circulante dos animais 4-6 horas após o tratamento. $O$ efeito em ambos os estágios evolutivos do T. cruzié aparentemente responsável pelos efeitos in vivo desse derivado que é o mais ativo composto já testado em nosso laboratório na doença de Chagas.

Palavras chaves: Trypanosoma cruzi. Nitroimidazol - Tiadiazole. Microscopia eletrônica

\section{REFERENCES}

1. Andrade SG, Figueira RM. Estudo experimental sobre a ação terapêutica da droga Ro 7-1051 na infecção por diferentes cepas do Trypanosoma cruzi. Revista do Instituto de Medicina Tropical de São Paulo 19: 335 $341,1977$.

2. Brener $\mathbf{Z}$. Therapeutic activity and criterion of cure on mice experimentally infected with Trypanosoma cruzi. Revista do Instituto de Medicina Tropical de São Paulo 4: 389-396, 1962.

3. Brener Z, Chiari E. Variações morfológicas observadas em diferentes amostras do Trypanosoma cruzi. Revista do Instituto de Medicina Tropical de São Paulo 5: 220$224,1963$.

4. Brener Z, Tafuri WL, Maria TA. An electron microscope study of Trypanosoma cruz $i$ intracellular forms in mice treated with an active nitrofuran compound. Revista do Instituto de Medicina Tropical de Sảo Paulo $11: 245-249,1969$.

5. Docampo R, Moreno SNJ, Stopanni AOM, Leon W, Cruz FE, Villalta F, Muniz RFA. Mechanism of ni- 
Maria TA, Filardi LS, Brener Z. Ultrastructural alterations of intracellular stages and effects on blood forms of Trypanosoma cruzi induced in vivo by 2-amino-5-(1-methyl-5-nitro-2-imidazolyl)-1, 3, 4-thiadiazole. Revista da Sociedade Brasileira de Medicina Tropical 17: 89-93, Abr-Jun, 1984

furtimox toxicity in different forms of Trypanosoma cruzi. Biochemistry Pharmacology 30: 1947-1951, 1981.

6. Filardi LS, Brener Z. A nitroimidazole-thiadiazole derivative with curative action in experimental Trypanosoma cruzi infections. Annals of Tropical Medicine and Parasitology 76: 293-297, 1982.

7. Filardi LS, Brener Z. A rapid method for testing in vivo the susceptibility of different strains of Trypanosoma cruzi to active chemotherapeutic agents. Memórias do Instituto Oswaldo Cruz (in press).

8. Haberkorn A, Gönnert R. Animal experimental investigations in the activity of nifurtimox against Trypanosoma cruzi. Arzneimittel Forschung 22: 1570-1581, 1972.

9. Lages-Silva E, Filardi LS, Gilbert ME, Gilbert B, Brener $Z$. Participation of macrophages in the clearance of
Trypanosoma cruzi from the blood of mice submitted to specific treatment. X Reuniāo Anual sobre Pesquisa Bàsica em Doenças de Chagas, Caxambu, novembro 1983.

10. Moreno SNJ, Docampo R, Mason RP, Leon W, Stopanni AOM. Different behaviour of benznidazole as free radical generator with mammalian and Trypanosoma cruzi microsomal preparations. Archives of Biochemistry and Biophysics 218: 585-591, 1983.

11. Schlemper Jr BR. Caracterização de cepas do Trypanosoma cruzi isoladas de pacientes com diferentes formas clinicas da doença de Chagas. Tese de Doutorado, Universidade Federal do Rio de Janeiro, Rio de Janeiro, 1982.

12. Voigt WH, Bock M, Gönnert R. Ultrastructural observations on the activity of nifurtimox on the causative organism of Chagas' disease. I. Trypanosoma cruzi in tissue cultures. Arzneimittel Forschung 22: 1586-1589, 1972. 